\title{
EFEK PENGURANGAN DIMENSI MOLD TERHADAP NILAI CBR-UNSOAKED MATERIAL CRUSHED LIMESTONE PANGANDARAN
}

\author{
Andrias Suhendra Nugraha ${ }^{1}$, Ahmad Fauzi Iqbal ${ }^{2}$ \\ ${ }^{1}$ Dosen Program Studi Teknik Sipil, Fakultas Teknik, Universitas Kristen Maranatha \\ dan Mahasiswa Program Doktor Ilmu Teknik Sipil, Universitas Katolik Parahyangan \\ ${ }^{2}$ Alumni Program Studi Teknik Sipil, Fakultas Teknik, Universitas Kristen Maranatha \\ Email: andrias.snugraha@gmail.com, rezafauziiqbal@yahoo.co.id
}

\begin{abstract}
ABSTRAK
California Bearing Ratio (CBR) adalah salah satu parameter geoteknik yang digunakan pada desain konstruksi jalan. Nilai CBR dapat diperoleh baik dari hasil pengujian material di laboratorium maupun di lapangan. Pada pelaksanaan uji CBR di laboratorium, dibutuhkan volume material uji yang cukup besar sehingga membutuhkan biaya yang mahal. Untuk mengurangi biaya dan kebutuhan material uji tersebut maka diperlukan suatu upaya untuk melakukan penelitian terhadap uji CBR laboratorium dengan menggunakan mold (cetakan) uji berdiameter lebih kecil (non-standard) dari mold standard untuk uji CBR.

Tujuan penelitian adalah mengevaluasi efek pengurangan dimensi mold terhadap nilai CBRunsoaked material crushed limestone. Material uji berasal dari daerah Pangandaran, Jawa Barat. Diameter mold uji non-standard yang digunakan untuk uji CBR antara lain adalah: 10,06 cm (mold standard Proctor), $7,94 \mathrm{~cm}$ (mold non-standard A), 4,96cm (mold non-standard B). Ukuran diameter piston $\simeq 1 / 3$ ukuran diameter mold.

Hasil penelitian menunjukkan bahwa rasio pengurangan diameter mold berbanding terbalik dengan rasio peningkatan nilai CBR-unsoaked. Rasio pengurangan dimensi mold uji non-standard terhadap dimensi mold uji CBR standard berturut-turut adalah; 0,66 (atau $\simeq 2 / 3$ ) untuk mold standard proctor, $0,52($ atau $\simeq 1 / 2)$ untuk mold non-standard $\mathrm{A}$, dan $0,33($ atau $\simeq 1 / 3)$ untuk mold non-standard B. Rasio peningkatan nilai California Bearing Ratio (CBR)-unsoaked dengan mold uji non-standard terhadap nilai CBR-unsoaked dengan mold uji CBR standard beturut-turut adalah; 1,67 (atau $\simeq$ 3/2) untuk uji dengan mold standard Proctor, 2,04 (atau $\simeq 2 / 1)$ untuk uji dengan mold non-standard $\mathrm{A}$, dan 3,08 (atau $\simeq 3 / 1$ ) untuk uji dengan mold non-standard B.
\end{abstract}

Kata kunci: CBR-unsoaked material crushed limestone, pengurangan dimensi mold

\begin{abstract}
California Bearing Ratio (CBR) is one of the geotechnical parameters used in road construction design. CBR values can be obtained both from the results of material testing in the laboratory and in the field. In conducting CBR tests in the laboratory, it requires a large enough volume of test material so that it requires expensive costs. To reduce the cost and requirement of the test material, an effort is needed to conduct research on a laboratory CBR test using a smaller diameter (non-standard) test mold than a standard mold for a CBR test.

The purpose of this study was to evaluate the effect of reducing mold dimensions on the value of CBR-unsoaked crushed limestone. Test material comes from the Pangandaran area, West Java. The non-standard test mold diameters used for the CBR tests respectively as follows : 10,06 $\mathrm{cm}$ (mold standard Proctor), 7,94cm (non-standard A mold), 4,96cm (non-standard B mold). The size of the piston diameter used for the CBR tests is adjusted to each test mold diameter, i.e : 1/3 the size of the mold diameter.

The results showed that, the reduction ratio of mold diameter is inversely proportional to the value of increment ratio of CBR-unsoaked value. The reduction ratio of non-standard mold dimension to standard mold dimension of CBR tests, respectively as follows; 0.66 (or $\simeq 2 / 3$ ) for standard Proctor mold, 0.52 (or $\simeq 1 / 2$ ) for non-standard A mold, and 0.33 (or $\simeq 1 / 3$ ) for non-standard mold $B$. The increament ratio in CBR-unsoaked value for CBR tests with non- non-standard mold to CBR tests with standard mold, respectively as follows; 1.67 (or $\simeq$ 3/2) for testing with standard
\end{abstract}


Proctor mold, 2.04 (or $\simeq 2 / 1$ ) for testing with non-standard A mold, and 3.08 (or $\simeq 3 / 1$ ) for testing with non-standard B mold.

Keywords: CBR-unsoaked of crushed limestone, dimesional mold reduction

\section{Pendahuluan}

Prasarana jalan merupakan salah satu komponen penting dalam bidang perekonomian. Infrastruktur jalan harus menjadi komitmen pemerintah pusat maupun pemerintah daerah guna mendukung konektivitas antar daerah yang memiliki keunggulan atau potensi yang berbeda-beda. Salah satu daerah yang memiliki pontensi tersebut adalah Kabupaten Pangandaran, Jawa Barat.

Potensi yang dimiliki pada Kabupaten Pangandaran adalah sektor pariwisata, sehingga prasarana jalan menuju wilayah tersebut harus dalam kondisi baik. Pembangunan infrastruktur jalan di wilayah sekitar Pangandaran terus menerus ditingkatkan agar tingkat konektivitas menuju wilayah tersebut bertambah tinggi. Hal ini akan berdampak pada pertumbuhan perekonomian, karena tingkat kemudahan untuk diakses oleh transportasi darat menjadi lebih tinggi.

Untuk setiap material yang akan digunakan pada suatu konstruksi jalan, perlu dilakukan tinjauan terhadap engineering properties untuk mendapatkan parameterparameter yang akan digunakan dalam perencanaan. Salah satu parameter geoteknik yang digunakan pada desain konstruksi jalan adalah nilai California Bearing Ratio (CBR). Nilai CBR dapat diperoleh dari hasil pengujian material di laboratorium baik untuk kondisi unsoaked (tidak terendam) maupun kondisi soaked (terendam). Pada pelaksanaannya, uji CBR laboratorium membutuhkan volume material yang cukup besar sehingga membutuhkan biaya yang mahal dan waktu pengujian yang lebih lama. Untuk mengurangi biaya dan penggunaan material yang banyak tersebut maka diperlukan suatu upaya penelitian antara lain adalah melakukan uji CBR laboratorium dengan menggunakan mold (cetakan) berdiameter lebih kecil (non-standard) dari mold standard uji CBR.

\section{Tujuan}

Tujuan dari penelitian ini adalah mengevaluasi efek pengurangan dimensi mold terhadap nilai California Bearing Ratio (CBR)-unsoaked material crushed limestone Pangandaran, Jawa Barat. 


\section{Ruang Lingkup}

Ruang lingkup studi adalah sebagai berikut:

1. Penelitian dilakukan dengan menggunakan material crushed limestone Pangandaran, Jawa Barat, dengan ukuran butir maksimum $=20 \mathrm{~mm}$;

2. Dimensi mold dan piston yang digunakan antara lain adalah :

a. Mold standard uji CBR

- Diameter mold $\quad=15,20 \mathrm{~cm}$;

- Tinggi mold $\quad=17,86 \mathrm{~cm}$;

- Diameter piston $=4,97 \mathrm{~cm}$;

b. Mold standard Proctor

- Diameter mold $\quad=10,06 \mathrm{~cm}$;

- Tinggi mold $=16,60 \mathrm{~cm}$;

- Diameter piston $=3,36 \mathrm{~cm}$;

c. Mold non-standard A

- Diameter mold $\quad=7,94 \mathrm{~cm}$;

- Tinggi mold $\quad=12,87 \mathrm{~cm}$;

- Diameter piston $=2,62 \mathrm{~cm}$;

d. Mold non-standard B

- Diameter mold $\quad=4,96 \mathrm{~cm}$;

- Tinggi mold $=12,91 \mathrm{~cm}$;

- Diameter piston $=1,66 \mathrm{~cm}$;

3. Tata cara pelaksanaan uji CBR laboratorium mengacu pada standar ASTM D-1883;

4. Tata cara pelaksanaan uji kompaksi mengacu pada standar ASTM D-698;

5. Energi kompaksi yang digunakan adalah sebesar $600 \mathrm{kN}-\mathrm{m} / \mathrm{m}^{3}$;

6. Digunakan hanya 1 (satu) desain gradasi untuk seluruh pengujian sampel uji CBR;

7. Uji CBR yang dilakukan adalah uji CBR-unsoaked (tidak terendam);

8. Pengujian dilakukan di Laboratorium Mekanika Tanah, Program Studi Teknik Sipil, Universitas Kristen Maranatha, Bandung.

\section{Material Crushed Limestone Pangandaran}

Lokasi pengambilan material uji (limestone) adalah di perbatasan Desa Putrapinggan, Kecamatan Kalipucang, Kabupaten Pangandaran, Jawa Barat. Titik pengambilan sampel tampak pada Gambar 1. Proses pengambilan material limestone di lapangan dibantu dengan alat berat excavator, seperti tampak pada Gambar 2. 


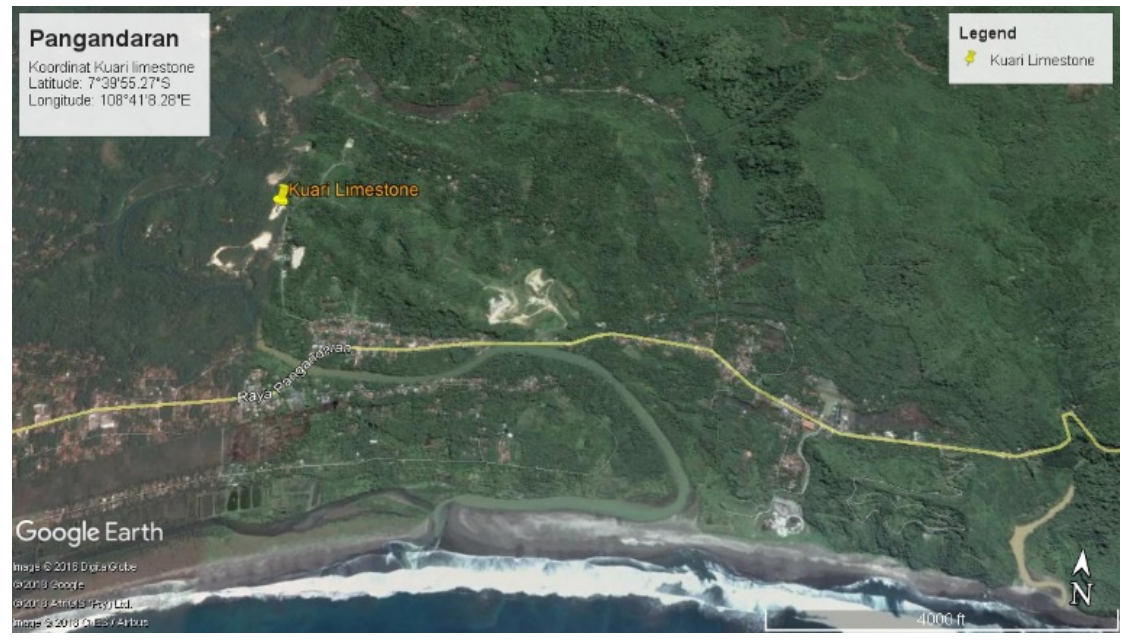

\section{Gambar 1. Titik Pengambilan Material Uji Limestone Pangandaran} Sumber: Google Maps

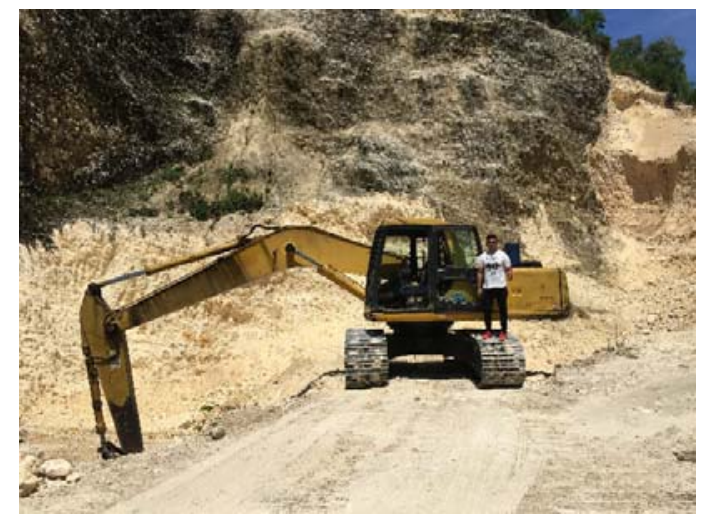

\section{Gambar 2. Pengambilan Material di Lapangan Dibantu oleh Excavator}

Berat total material limestone yang tiba di laboratorium dan akan dijadikan sebagai material uji pada penelitian ini adalah : $140 \mathrm{~kg}$, yang terbagi menjadi 3 (tiga) karung seperti tampak pada Gambar 3. 


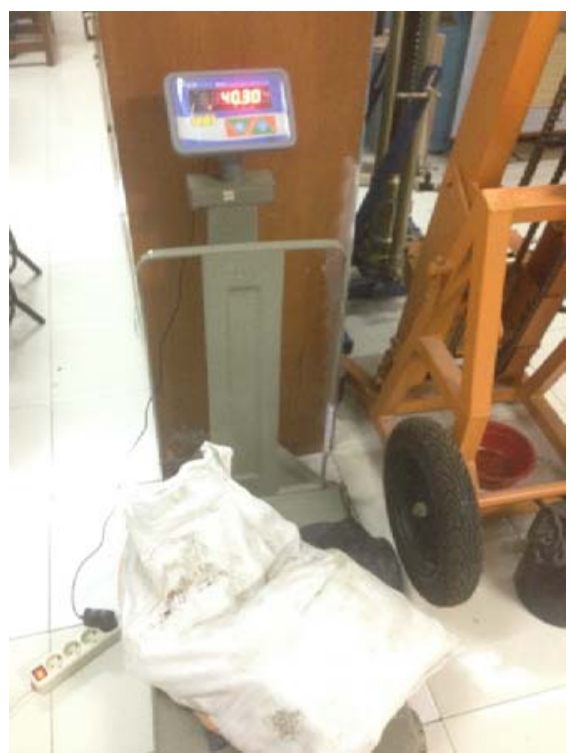

(a)

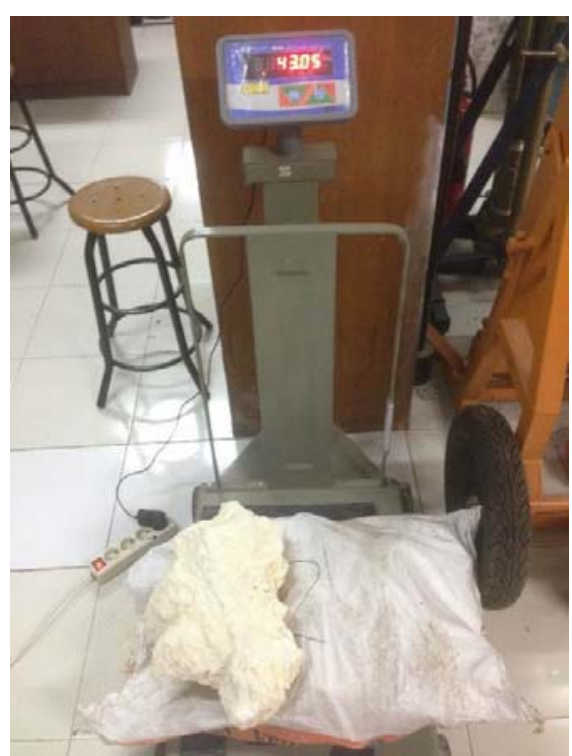

(b)

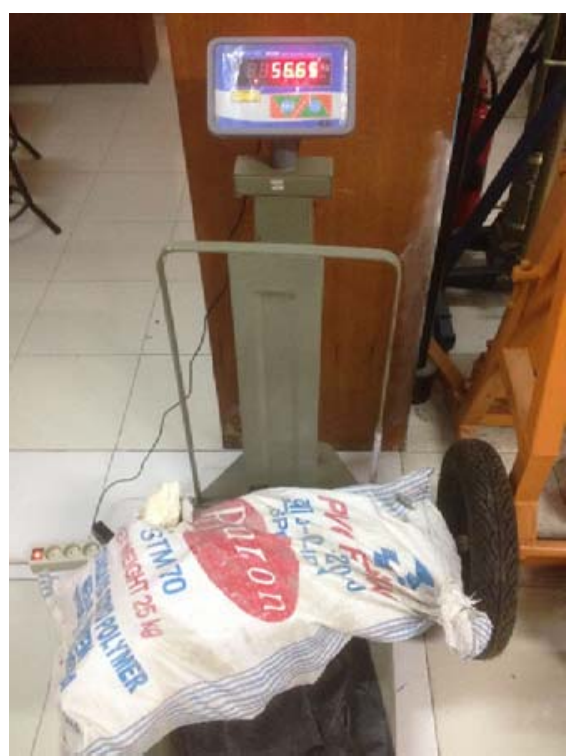

(c)

Gambar 3. Material Limestone Saat Tiba di Laboratoium (a) Karung 1 (40,30kg) (b) Karung $2(43,05 \mathrm{~kg})$ (c) Karung 3 (56,65kg)

Ukuran awal dari material limestone yang berasal dari quarry adalah berupa cobbles dan boulder (grain size : 75 - 300mm) seperti tampak pada Gambar 4. 


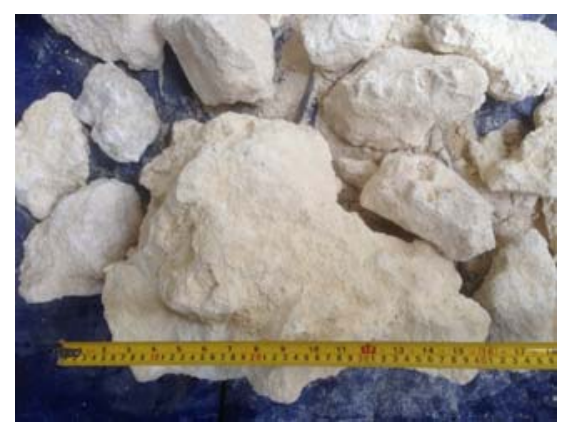

\section{Gambar 4. Limestone Pangandaran berukuran Cobbles dan Boulder $(75-300 \mathrm{~mm})$ Saat Tiba di Laboratorium}

Untuk mendapatkan ukuran butir yang akan digunakan sebagai sampel uji, material limestone yang berasal dari quarry mengalami proses crushing di laboratorium. Proses crushing (penghancuran) dilakukan dengan cara proses manual dengan menggunakan pahat dan palu, seperti tampak pada Gambar 5.

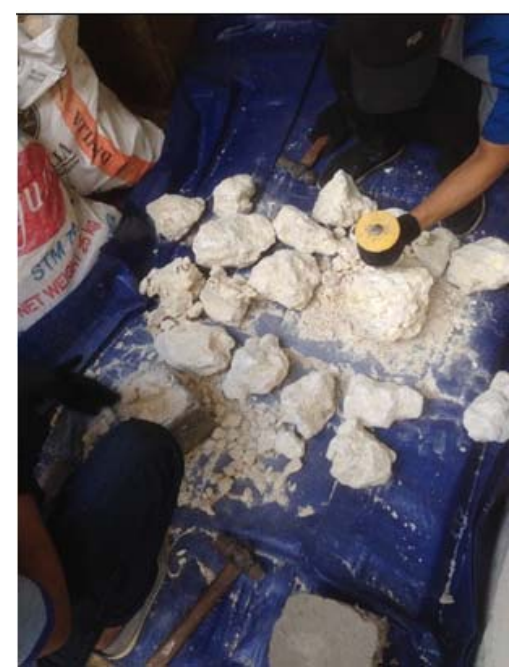

\section{Gambar 5. Proses Crushing Manual untuk Material Limestone Pangandaran}

Seluruh material limestone yang digunakan untuk pengujian CBR-unsoaked di laboratorium adalah material yang lolos ayakan (sieve) dengan ukuran bukaan (sieve opening) : $20 \mathrm{~mm}$. Selanjutnya untuk seluruh material uji akan dilakukan uji sieve analysis. Hasil dari proses uji sieve analysis dinyatakan pada Tabel 1.

\section{Tabel 1. Hasil Uji Sieve Analysis untuk Desain Gradasi} Material Crushed Limestone Pangandaran 


\begin{tabular}{cccccr}
\hline $\begin{array}{c}\text { Sieve } \\
\text { No. }\end{array}$ & $\begin{array}{c}\text { Sieve Opening } \\
(\mathbf{m m})\end{array}$ & $\begin{array}{c}\text { Berat Tanah } \\
\text { Tertahan } \\
\mathbf{( g r )}\end{array}$ & $\begin{array}{c}\text { Persen } \\
\text { Tertahan } \\
\mathbf{( \% )}\end{array}$ & $\begin{array}{c}\text { Persen } \\
\text { Kum. } \\
\text { Tertahan } \\
\mathbf{( \% )}\end{array}$ & $\begin{array}{r}\text { Persen } \\
\text { Lolos } \\
(\mathbf{\%})\end{array}$ \\
\hline 1 & 20 & 0 & 0 & 0 & 100 \\
2 & 10 & 48750 & 39,55 & 39,55 & 60,45 \\
4 & 4,75 & 32431 & 26,31 & 65,87 & 34,13 \\
10 & 2,00 & 13995,0 & 11,35 & 77,22 & 22,78 \\
20 & 0,85 & 9341,0 & 7,58 & 84,80 & 15,20 \\
40 & 0,43 & 6212,2 & 5,04 & 89,84 & 10,16 \\
50 & 0,30 & 480,0 & 0,39 & 90,23 & 9,77 \\
100 & 0,15 & 3836,5 & 3,11 & 93,34 & 6,66 \\
200 & 0,08 & 4541,0 & 3,68 & 97,03 & 2,97 \\
Pan & & 3664 & 2,97 & 100,00 & 0,00 \\
Total & & $\mathbf{1 2 3 2 5 0 , 7}$ & $\mathbf{1 0 0}$ & & \\
\hline
\end{tabular}

Kurva distribusi ukuran butir dari material crushed limestone tampak pada Gambar 6. Kurva ini dijadikan sebagai acuan desain gradasi untuk setiap material crushed limestone yang akan diuji CBR-unsoaked di laboratorium.

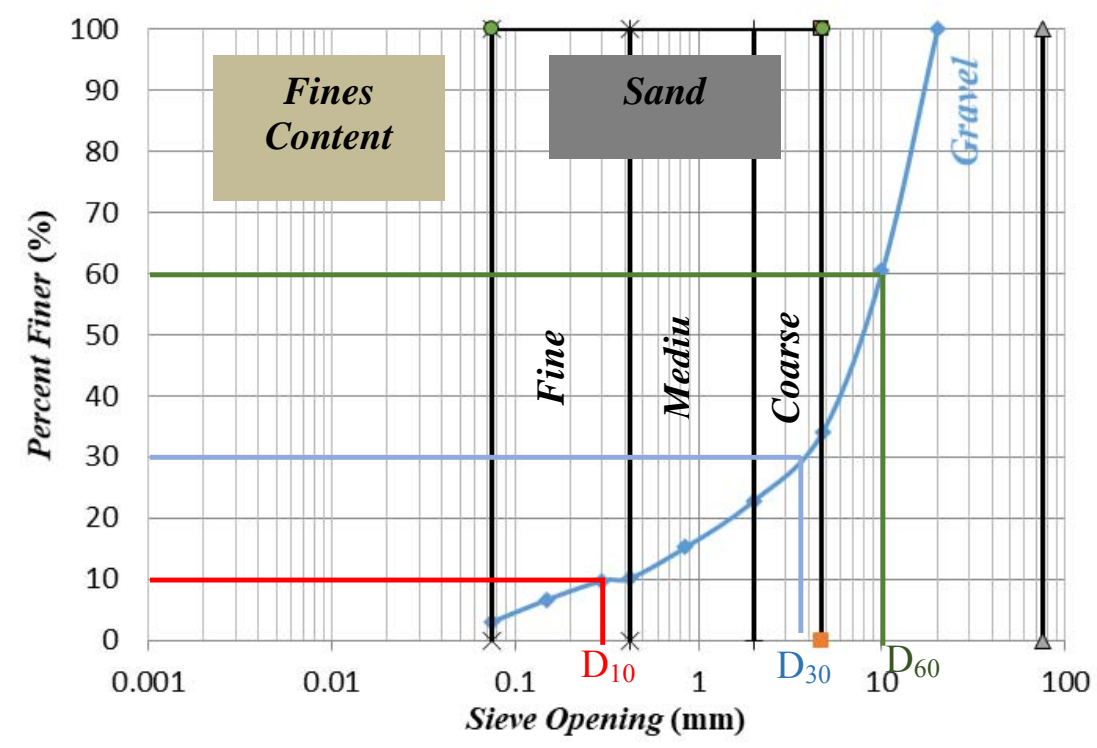

Gambar 6. Kurva Distribusi Ukuran Butir

Hasil uji sieve analysis dapat juga juga digunakan untuk dapat mengetahui coefficient of uniformity (koefisien keseragaman), $\mathrm{C}_{\mathrm{u}}$, coefficient of curvature (koefisien 
gradasi), $\mathrm{C}_{\mathrm{c}}$, nilai \% fines (persen material yang lolos saringan $0.075 \mathrm{~mm}$ ) serta jenis gradasi dari material uji. Parameter $\mathrm{C}_{\mathrm{u}}$ dan $\mathrm{C}_{\mathrm{c}}$ diperoleh dengan menggunakan persamaan sebagai berikut :

$$
\begin{aligned}
& C_{u}=\frac{D_{60}}{D_{10}} \\
& C_{c}=\frac{D_{30}{ }^{2}}{D_{60} \cdot D_{10}}
\end{aligned}
$$

dimana:

$$
\begin{aligned}
& D_{10}=\text { diameter yang bersesuaian dengan } 10 \% \text { lolos ayakan (sieve) } \\
& D_{30}=\text { diameter yang bersesuaian dengan } 30 \% \text { lolos ayakan (sieve) } \\
& D_{60}=\text { diameter yang bersesuaian dengan } 60 \% \text { lolos ayakan (sieve) }
\end{aligned}
$$

Penentuan jenis gradasi material crushed limestone Pangandaran dilakukan berdasarkan parameter-parameter yang diperoleh dari hasil uji sieve analysis (lihat Tabel 1 dan Gambar 6). Jenis gradasi material crushed limestone Pangandaran adalah poorly graded (bergradasi buruk), seperti dinyatakan pada Tabel 2.

Tabel 2. Penentuan Jenis Gradasi dari Material Crushed Limestone Pangandaran

\begin{tabular}{cc}
\hline Parameter & \\
\hline $\mathrm{D}_{10}$ & $0,3 \mathrm{~mm}$ \\
$\mathrm{D}_{30}$ & $3,8 \mathrm{~mm}$ \\
$\mathrm{D}_{60}$ & $10 \mathrm{~mm}$ \\
Fines Content (\% Fines) & $2,97 \%$ \\
Coefficient of Uniformity $\left(\mathrm{C}_{\mathrm{u}}\right)$ & 33,33 \\
Coefficient of Curvature $\left(\mathrm{C}_{\mathrm{c}}\right)$ & 4,8 \\
Jenis Gradasi & Poorly Graded \\
\hline
\end{tabular}

Seluruh material limestone yang telah melalui proses crushing manual selanjutnya disebut sebagai material crushed limestone. Untuk setiap material crushed limestone yang tertahan disetiap nomor saringan, masing-masing ditempatkan/dikelompokan pada kantong plastik yang telah ditandai dengan nomor sieve seperti tampak pada Gambar 7. 


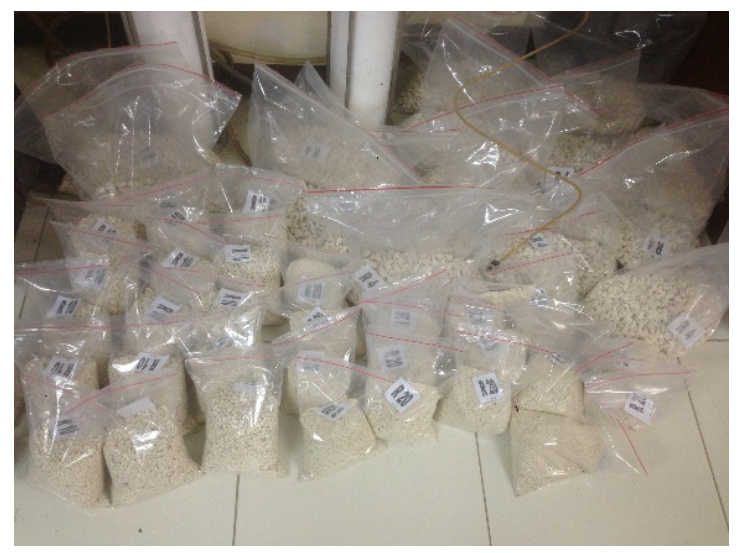

\section{Gambar 7. Material Crushed Limestone Pangadaran Dikelompokan Sesuai dengan Ukuran Nomor Sieve}

\section{Uji Califoria Bearing Ratio (CBR)}

California Bearing Ratio adalah rasio dari gaya perlawanan penetrasi (penetration resistance) dari tanah terhadap penetrasi sebuah piston yang ditekan secara kontinu dengan gaya perlawanan penetrasi serupa pada contoh tanah standar berupa batu pecah di California. Rasio tersebut diambil pada penetrasi $2.5 \mathrm{~mm}$ dan $5.0 \mathrm{~mm}(0.1$ inci dan 0.2 inci) dengan ketentuan angka/nilai tertinggi yang digunakan. Gaya perlawanan penetrasi adalah gaya yang diperlukan untuk menahan penetrasi konstan dari suatu piston ke dalam tanah.

Penentuan nilai CBR dilakukan dengan menggunakan persamaan berikut ini :

$$
\begin{aligned}
& C B R_{0,1^{\prime \prime}}=\frac{\text { Load pada penetrasi 0,1" }}{1000 \times \text { Luas Piston }} \\
& C B R_{0,2^{\prime \prime}}=\frac{\text { Load pada penetrasi 0,2" }}{1500 \times \text { Luas Piston }}
\end{aligned}
$$

dimana :

Load = Proving ring dial $\mathrm{x}$ Proving ring calibration

Pengujian CBR-unsoaked di laboratorium mengacu pada standar ASTM D-1883. Alat uji CBR dan mold uji CBR tampak pada Gambar 8 dan Gambar 9. 


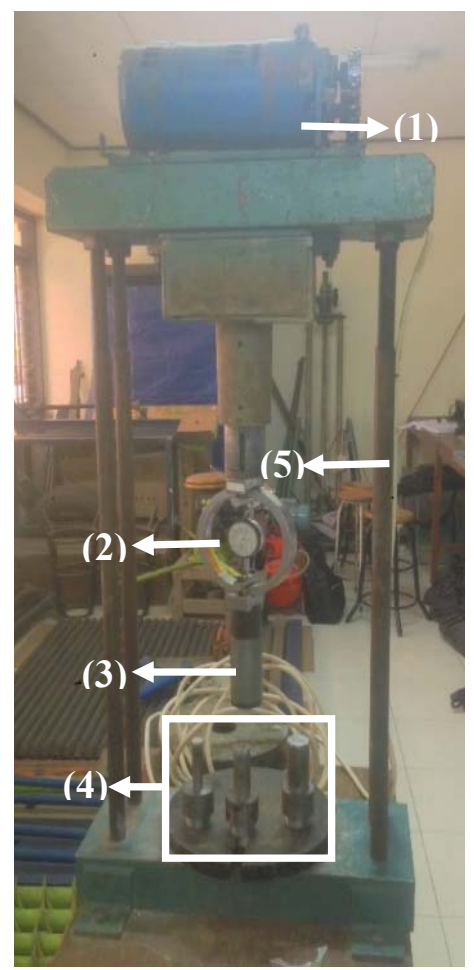

Keterangan :
(1) Motor Penggerak
(2) Proving Ring
(3) Piston Standard(4) Piston Non-Standard
(5) Loading Frame

(a)

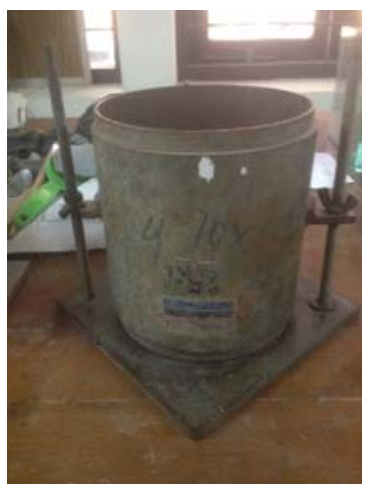

(b)

Gambar 8. (a) Alat Uji CBR (b) Mold Standard untuk Uji CBR 


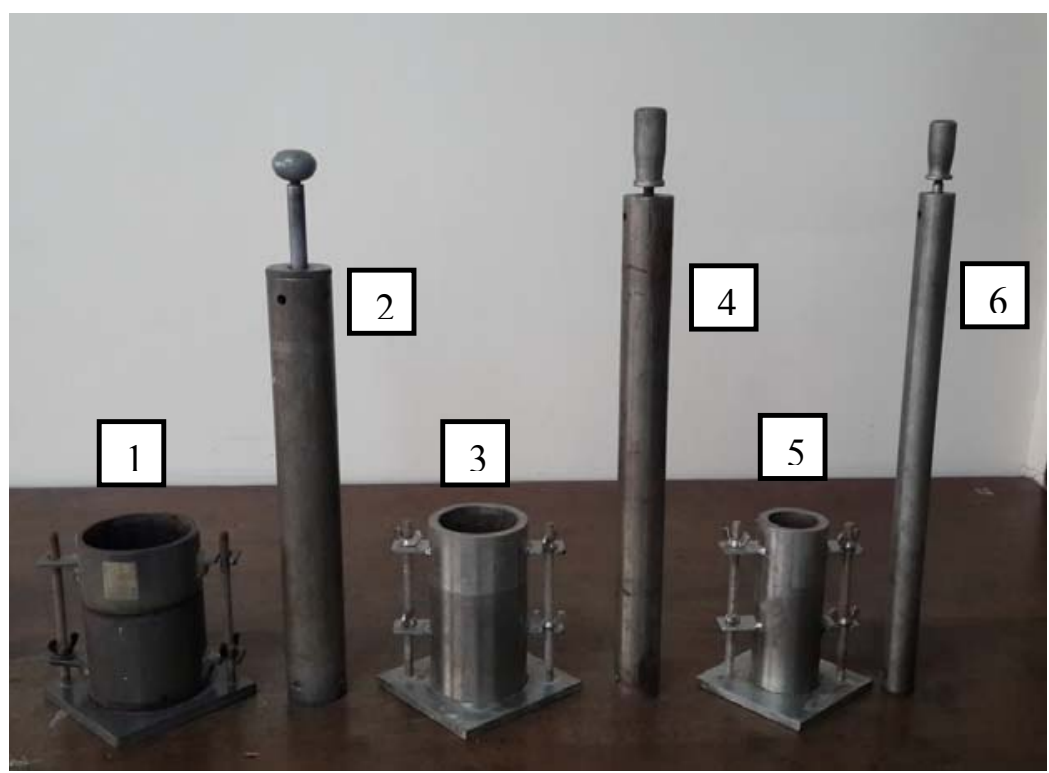

1. Mold Standard Proctor

4. Rammer Non-Standard A

2. Rammer

Standard

5. Mold Non-Standard B

3. Mold Non-Standard A

6. Rammer Non-Standard B

\section{Gambar 9. Mold Non-Standard untuk Uji CBR}

\section{Hasil Uji dan Analisis}

\subsection{Hasil Uji Indeks Properti Material Crushed Limestone Pangandaran}

Hasil uji indeks properti yang telah dilakukan pada material crushed limestone Pangandaran adalah kadar air (water content) dan berat jenis (specific gravity). Hasil uji indeks properti tampak pada Tabel 3.

Tabel 3. Indeks Properti Material Uji Crushed Limestone

\begin{tabular}{|c|c|c|}
\hline Material Uji & $\begin{array}{c}\text { WaterContent, } \\
\mathbf{w}(\%)\end{array}$ & Specific Gravity, $\mathbf{G}_{\mathbf{s}}$ \\
\hline $\begin{array}{c}\text { Crushed } \\
\text { Limestone } \\
\text { Pangandaran }\end{array}$ & 0,09 & 2,65 \\
\hline
\end{tabular}




\subsection{Hasil Uji CBR-Unsoaked Material Crushed Limestone Pangandaran}

Setiap hasil uji CBR di laboratorium dapat dinyatakan dengan menggunakan kurva load-penetration. Hasil uji CBR-unsoaked pada posisi top layer untuk material crushed limestone dengan menggunakan mold standard CBR tampak Gambar 10. Pada Gambar 10 tersebut ditunjukkan bahwa kurva load-penetration pada pengujian 2 ( $2^{\text {nd }}$ test) lebih tinggi dari pengujian 1 ( $1^{\text {st }}$ test), tetapi kedua kurva tersebut memiliki kecenderungan (trend) yang sama.

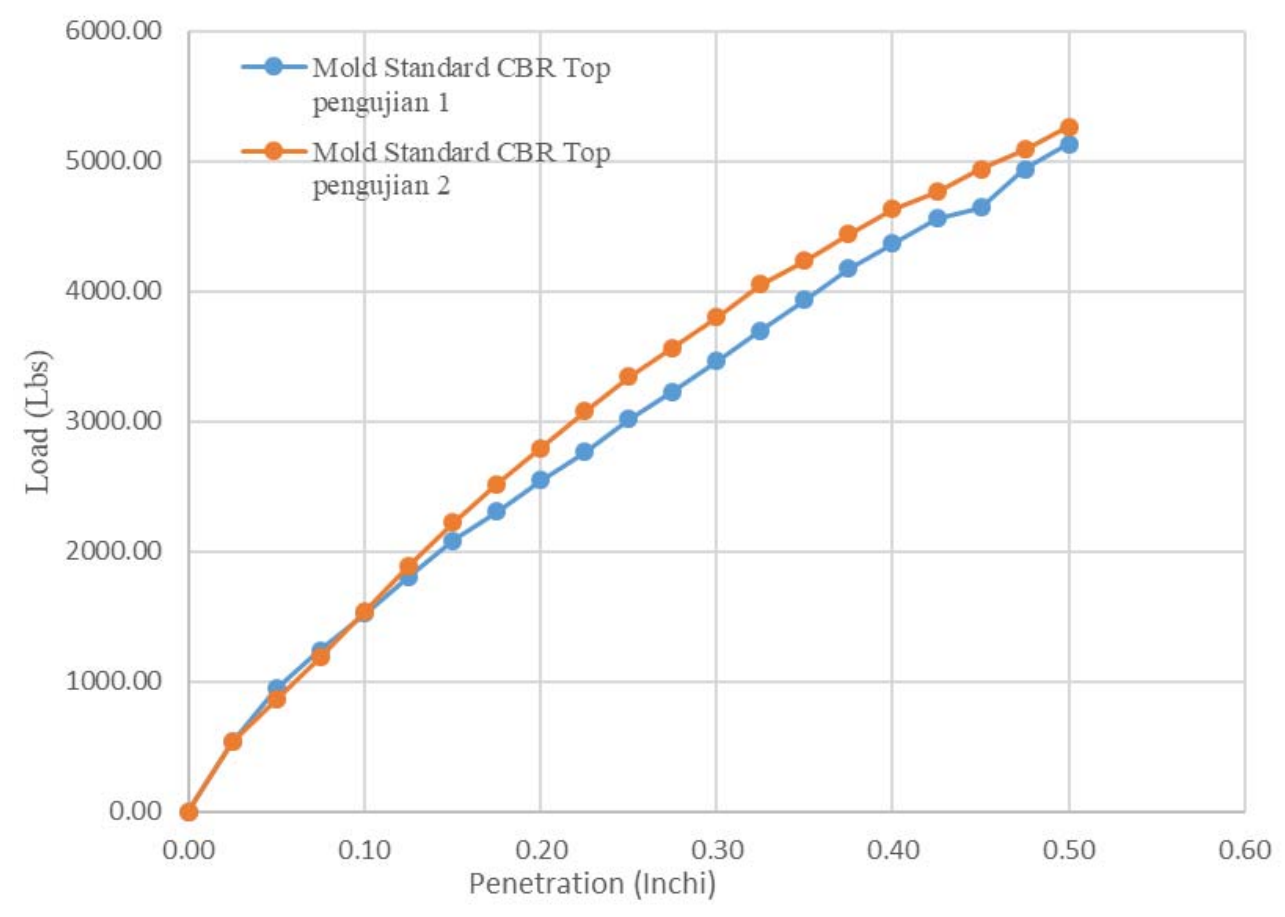

\section{Gambar 10. Kurva Load-Penetration Uji CBR dengan Mold Standard (Top)}

Hasil pengujian CBR-unsoaked pada posisi bottom layer untuk material crushed limestone dengan menggunakan mold standard CBR tampak pada Gambar 11. Kurva load-penetration pada Gambar 11 tersebut menunjukkan bahwa bentuk kurva pengujian 1 $\left(1^{\text {st }}\right.$ test) dan kurva pengujian 3 ( $3^{\text {rd }}$ test $)$ memiliki trend yang sama. Pada pengujian $2\left(2^{\text {nd }}\right.$ test), uji CBR mengalami kondisi dimana penetrasi piston tidak bergerak tegak lurus seperti terlihat pada Gambar 12, sehingga kurva load- penetration untuk pengujian 2 tidak dapat digunakan untuk analisis selanjutnya. 


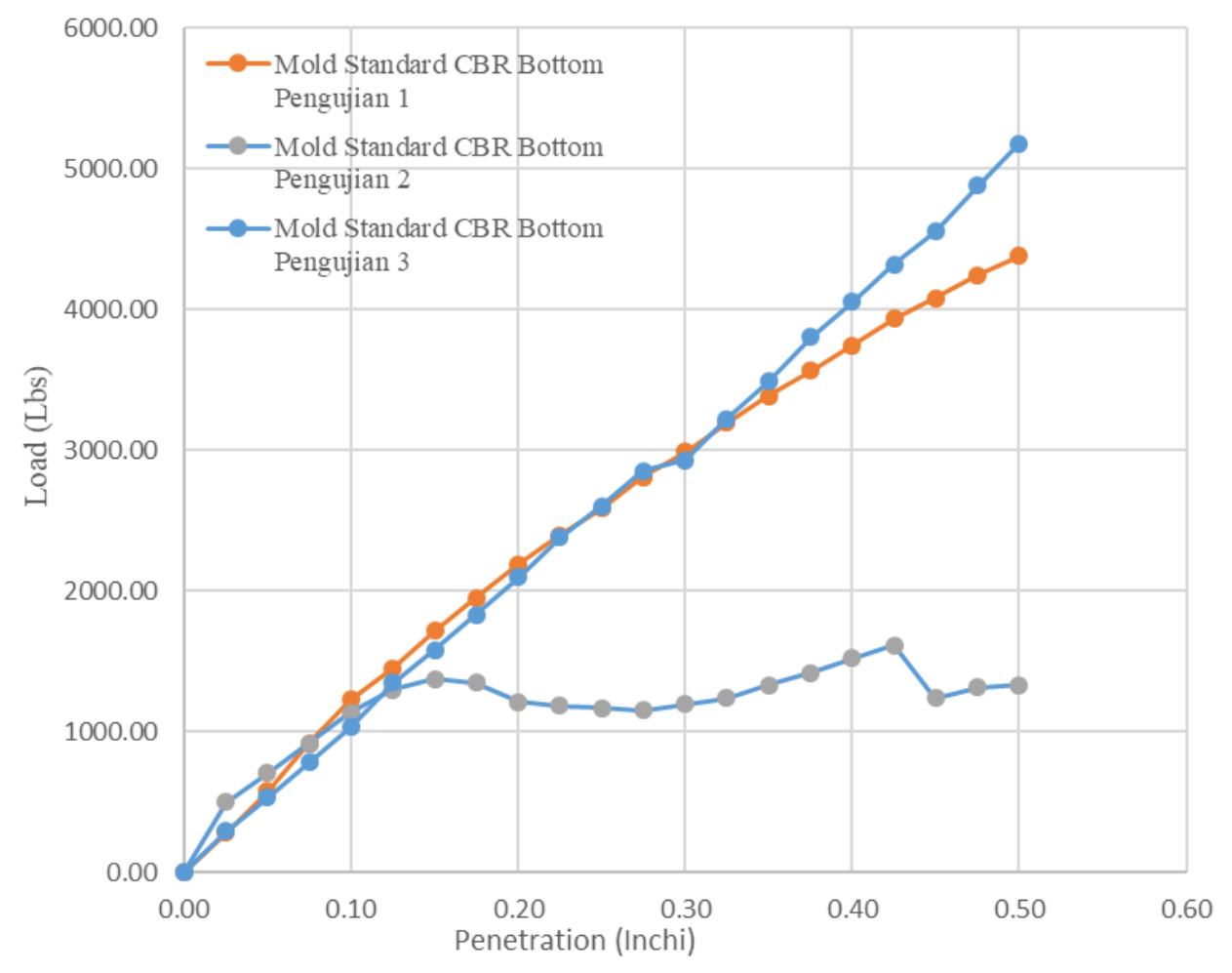

\section{Gambar 11. Kurva Load-Penetration Uji CBR dengan Mold Standard} (Bottom)

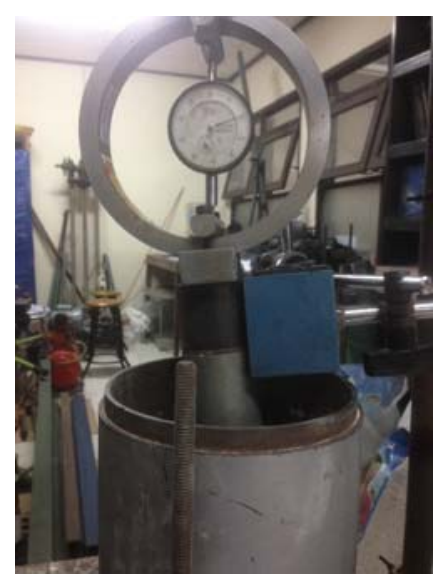

\section{Gambar 12. Posisi Piston saat Pengujian $2\left(2^{\text {nd }}\right.$ Test $)$}

Untuk menjaga kondisi posisi piston tetap tegak lurus dan kejadian pada pengujian 2 tidak berulang, maka digunakan alat penyangga piston sehingga penetrasi piston saat uji CBR dapat berjalan dengan baik. Alat penyangga piston dapat dilihat pada Gambar 13. 


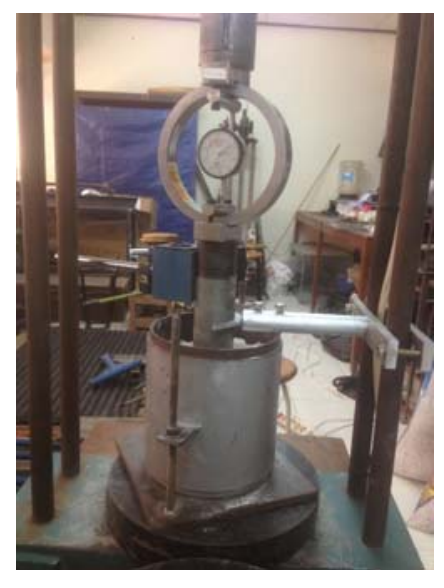

\section{Gambar 13. Alat Penyangga Piston}

Hasil pengujian CBR-unsoaked material crushed limestone dengan menggunakan mold standard Proctor tampak pada Gambar 14.

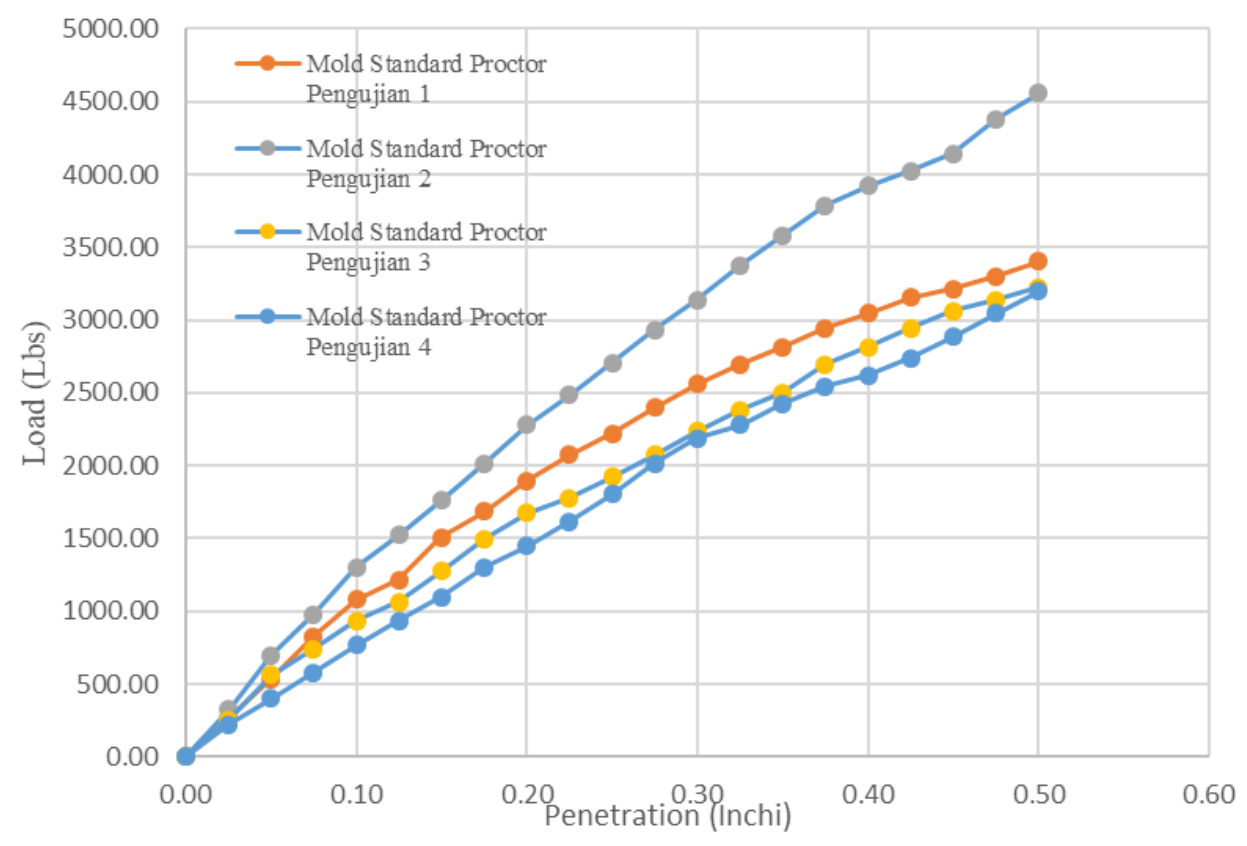

\section{Gambar 14. Kurva Load-Penetration Uji CBR dengan Mold Standard Proctor}

Pada Gambar 14 ditunjukkan bahwa pengujian 1 ( $1^{\text {st }}$ test $)$, pengujian 3 ( $3^{\text {rd }}$ test $)$ dan pengujian 4 ( $4^{\text {th }}$ test) memilik trend kurva load-penetration yang sama.

Hasil pengujian CBR-unsoaked material crushed limestone dengan menggunakan mold non standard-A dapat dilihat pada Gambar 15. 


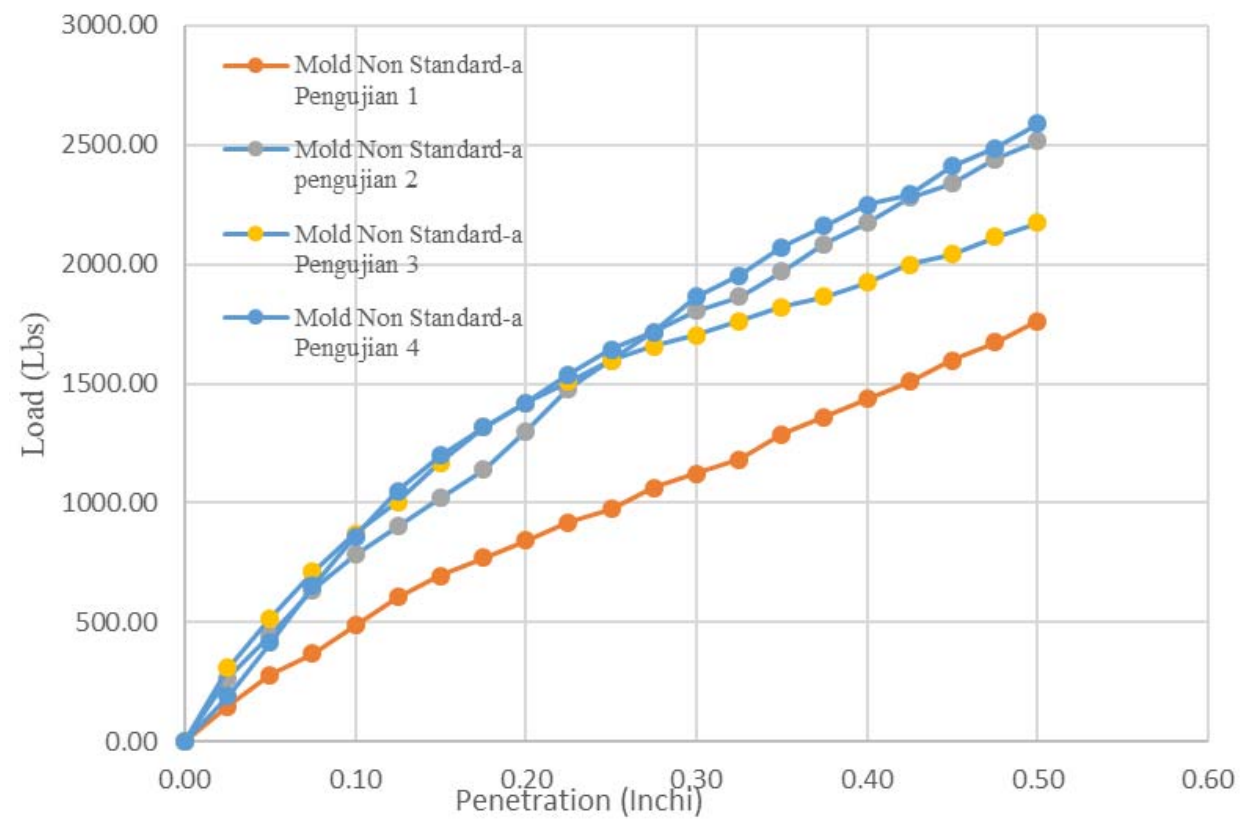

Gambar 15. Kurva Load-Penetration Uji CBR dengan Mold Non Standard-A

Gambar 15 menunjukkan bahwa, kurva load-penetration dengan trend yang sama terjadi untuk pengujian 2 ( $2^{\text {nd }}$ test), pengujian 3 ( $3^{\text {rd }}$ test), dan pengujian 4 ( $4^{\text {th }}$ test). Sementara kurva load-penetration untuk pengujian 1 ( $1^{\text {st }}$ test) memiliki trend yang berbeda.

Hasil pengujian CBR-unsoaked material crushed limestone dengan menggunakan mold non standard-B dapat dilihat pada Gambar 16. Pada Gambar 16 ditunjukkan pula bahwa, kurva load-penetration dengan trend yang sama terjadi untuk pengujian 1 ( $1^{\text {st }}$ test), pengujian 2 ( $2^{\text {nd }}$ test $)$, pengujian 3 ( $3^{\text {rd }}$ test $)$, dan pengujian $5\left(5^{\text {th }}\right.$ test $)$. Sementara kurva load-penetration untuk pengujian 4 ( $4^{\text {th }}$ test) memiliki trend yang berbeda. 


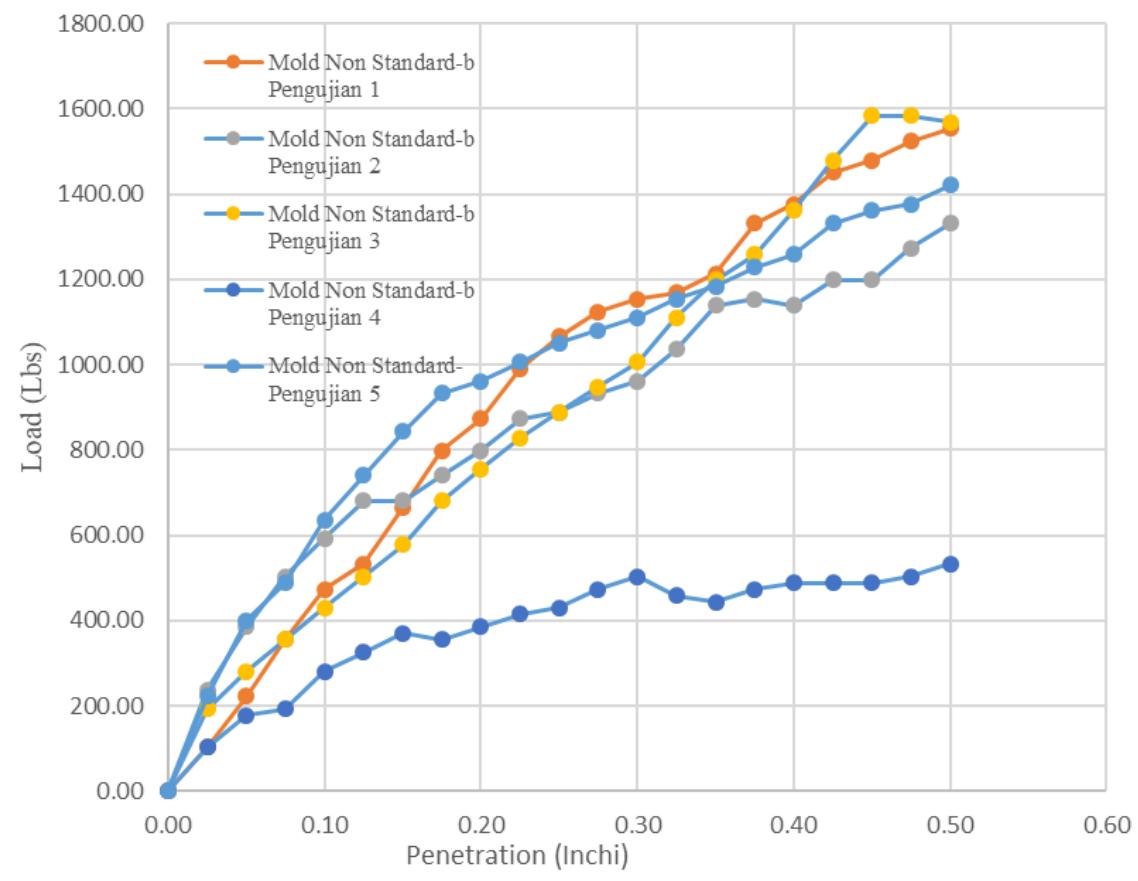

Gambar 16. Kurva Load-Penetration Uji CBR dengan Mold Non Standard-B

Analisa nilai CBR-unsoaked dengan menggunakan mold standard uji CBR, mold standard Proctor, mold non standard-A, dan mold non standard-B dan penentuan nilai CBR-unsoaked yang representatif untuk setiap uji CBR dengan jenis mold uji (5 varian) dinyatakan pada Tabel 4 dan Gambar 17.

Tabel 4. Penentuan Nilai CBR-Unsoaked Material Crushed Limestone

\begin{tabular}{cccccc}
\hline Test & \multicolumn{5}{c}{ Jenis Mold } \\
\cline { 2 - 6 } & $\begin{array}{c}\text { Standard } \\
\text { CBR } \\
\text { Pada Posisi } \\
\text { Top }\end{array}$ & $\begin{array}{c}\text { Standard } \\
\text { CBR } \\
\text { Pada Posisi } \\
\text { Bottom }\end{array}$ & $\begin{array}{c}\text { Standard } \\
\text { Proctor }\end{array}$ & $\begin{array}{c}\text { Non } \\
\text { Standard } \\
\text { Mold-A }\end{array}$ & $\begin{array}{c}\text { Non } \\
\text { Standard } \\
\text { Mold-B }\end{array}$ \\
\cline { 2 - 6 } & \multicolumn{5}{c}{ CBR* (\%) } \\
\hline $1^{\text {st }}$ & $\mathbf{5 6 , 5 7}$ & $\mathbf{4 8 , 6 8}$ & 92,18 & 67,33 & 173,63 \\
$2^{\text {nd }}$ & 62,16 & 37,99 & 110,91 & $\mathbf{1 0 3 , 9 6}$ & 166,62 \\
$3^{\text {rd }}$ & - & 46,70 & $\mathbf{8 1 , 3 8}$ & 113,41 & $\mathbf{1 5 0 , 0 9}$ \\
$4^{\text {th }}$ & - & - & 70,58 & 113,41 & 79,14 \\
$5^{\text {th }}$ & - & - & - & - & 191,29 \\
$\begin{array}{c}\text { CBR }- \\
\text { unsoaked } \\
(\%)\end{array}$ & $\mathbf{5 6 , 5 7}$ & $\mathbf{4 8 , 6 8}$ & $\mathbf{8 1 , 3 8}$ & $\mathbf{1 0 3 , 9 6}$ & $\mathbf{1 5 0 , 0 9}$ \\
\hline
\end{tabular}




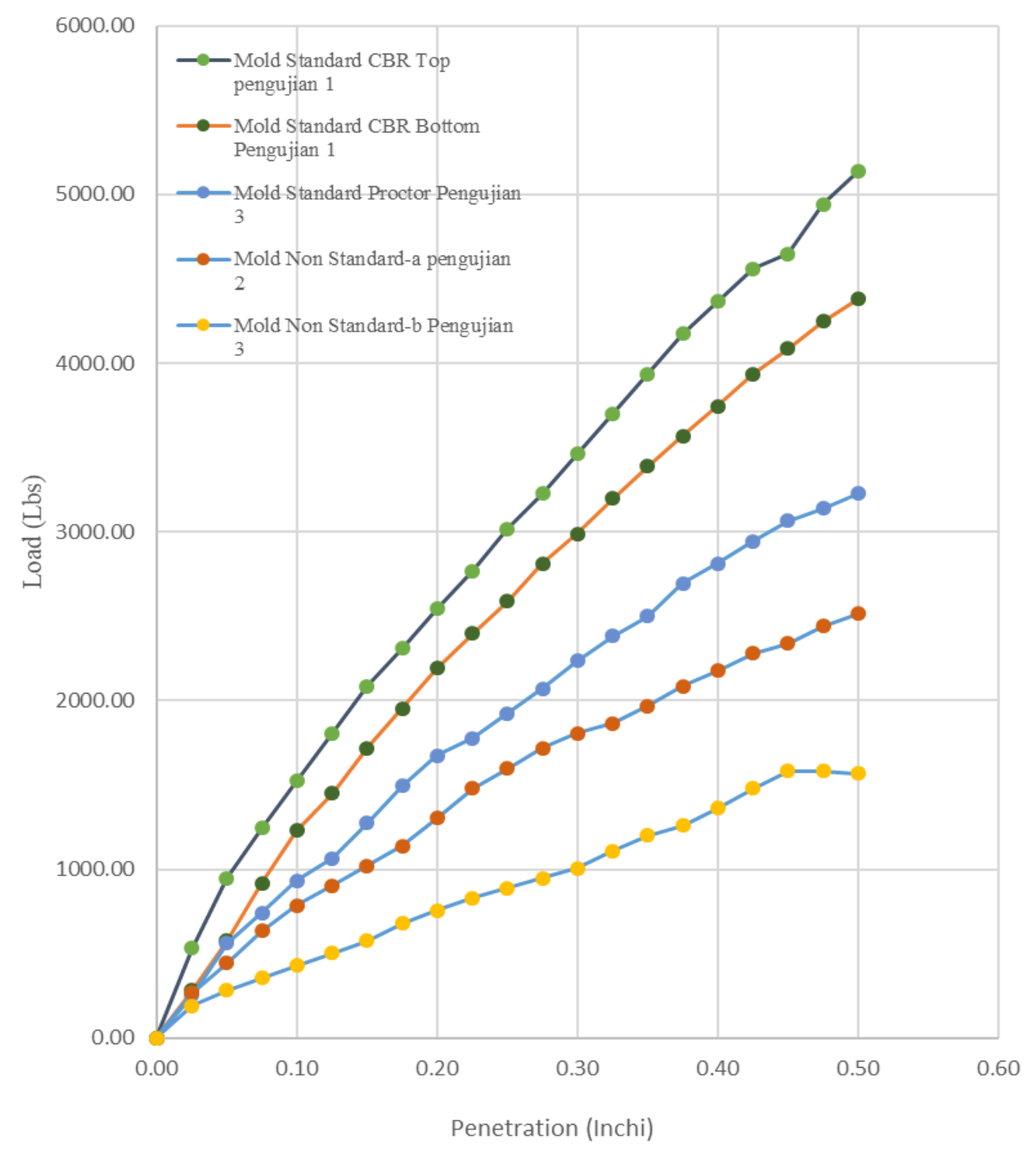

\section{Gambar 17. Kurva Load-Penetration Representatif untuk Setiap Uji CBR-Unsoaked dengan Variasi Mold}

Gambar 17 menunjukan bahwa seluruh kurva load-penetration dengan dimensi mold yang berbeda menghasilkan kecenderungan (trend) kurva yang sama yaitu strain hardening tetapi dengan kapasitas load yang berbeda untuk setiap jenis mold. 


\subsection{Analisa Efek Pengurangan Dimensi Mold Terhadap Nilai CBR-Unsoaked Material Crushed Limestone Pangandaran}

Analisa efek pengurangan dimensi Mold terhadap nilai CBR-unsoaked material crushed limestone Pangandaran dengan menggunakan mold standard, mold standard Proctor, mold non standard-A, dan mold non standard-B dinyatkan pada Tabel 5. Nilai CBR-unsoaked pada posisi bottom dengan menggunakan dimensi mold standard CBR dijadikan sebagai acuan untuk analisa rasio peningkatan nilai CBR-unsoaked dan rasio pengurangan dimensi mold.

Tabel 5. Efek Pengurangan Dimensi Mold Terhadap Nilai CBR-unsoaked Material Crushed Limestone Pangandaran

\begin{tabular}{|c|c|c|c|c|c|}
\hline \multirow[b]{2}{*}{ Test } & \multicolumn{5}{|c|}{ Jenis Mold } \\
\hline & $\begin{array}{c}\text { Standard } \\
\text { CBR } \\
\text { Pada Posisi } \\
\text { Top } \\
\end{array}$ & $\begin{array}{c}\text { Standard } \\
\text { CBR } \\
\text { Pada Posisi } \\
\text { Bottom } \\
\end{array}$ & $\begin{array}{l}\text { Standard } \\
\text { Proctor }\end{array}$ & $\begin{array}{c}\text { Non } \\
\text { Standard } \\
\text { Mold-A }\end{array}$ & $\begin{array}{c}\text { Non } \\
\text { Standard } \\
\text { Mold-B }\end{array}$ \\
\hline $\begin{array}{l}\text { CBR- } \\
\text { unsoaked } \\
(\%)\end{array}$ & 56,57 & 48,68 & 81,38 & 103,96 & 150,09 \\
\hline $\begin{array}{c}\text { Rasio } \\
\text { peningkatan } \\
\text { nilai } \\
\text { CBR- } \\
\text { unsoaked } \\
\end{array}$ & & & 1,67 & 2,14 & 3,08 \\
\hline $\begin{array}{c}\text { Diameter } \\
\text { mold } \\
(\mathrm{cm})\end{array}$ & 15,20 & 15,20 & 10,06 & 7,94 & 4,96 \\
\hline $\begin{array}{c}\text { Rasio } \\
\text { pengurangan } \\
\text { diameter } \\
\text { mold }\end{array}$ & & & 0,66 & 0,52 & 0,33 \\
\hline $\begin{array}{c}\text { Energi } \\
\text { pemadatan } \\
\left(\mathrm{kN}-\mathrm{m} / \mathrm{m}^{3}\right)\end{array}$ & 600 & 600 & 600 & 600 & 600 \\
\hline
\end{tabular}

Tabel 5 menunjukan bahwa pengurangan dimensi mold berdampak terhadap peningkatan nilai CBR. Hal ini diduga disebabkan oleh jarak antara titik pusat penetrasi piston terhadap dinding mold semakin dekat. Selain itu pada Tabel 5 tersebut, ditunjukkan pula bahwa rasio dimensi mold berbanding terbalik dengan rasio peningkatan nilai CBR.

Efek pengurangan diameter mold terhadap nilai CBR-unsoaked material crushed limestone Pangandaran tampak pada Gambar 18. 


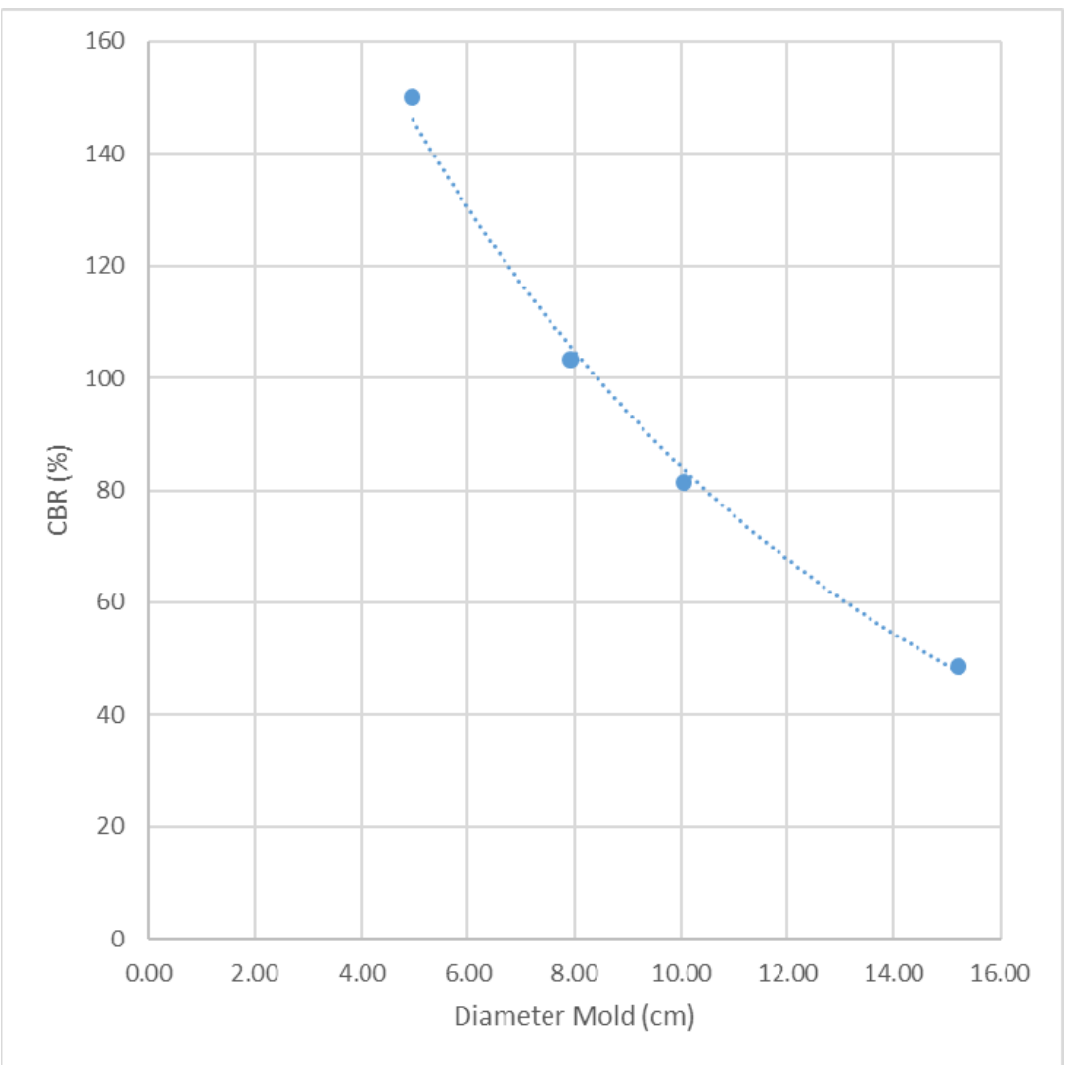

\section{Gambar 18. Kurva Efek Pengurangan Diameter Mold Terhadap Nilai CBR-unsoaked}

Gambar 18 menunjukan bahwa semakin kecil dimensi (diameter) mold maka nilai CBR-unsoaked semakin besar, hal ini pun diduga salah satunya disebabkan oleh jarak dari titik pusat penetrasi piston terhadap dinding mold semakin dekat seiring dengan pengurangan dimensi mold.

\section{Simpulan}

Kesimpulan yang diperoleh dari studi ini antara lain adalah :

1. Pengujian CBR-unsoaked dengan menggunakan mold CBR standard dan kondisi piston di posisi top layer menghasilkan nilai $\mathrm{CBR}=56,57 \%$.

2. Pengujian CBR-unsoaked dengan menggunakan mold CBR standard dan kondisi piston di posisi bottom layer menghasilkan nilai $\mathrm{CBR}=48,68 \%$.

3. Pengujian CBR-unsoaked dengan menggunakan mold standard Proctor menghasilkan nilai $\mathrm{CBR}=81,38 \%$.

4. Pengujian CBR-unsoaked dengan menggunakan mold non-standard A menghasilkan nilai $\mathrm{CBR}=103,96 \%$. 
5. Pengujian CBR-unsoaked dengan menggunakan mold non-standard B menghasilkan nilai $\mathrm{CBR}=150,09 \%$.

6. Rasio pengurangan dimensi mold uji non-standard terhadap dimensi mold uji CBR standard berturut-turut adalah; 0,66 (atau $\simeq 2 / 3$ ) untuk mold standard proctor, 0,52 (atau $\simeq 1 / 2$ ) untuk mold non-standard $\mathrm{A}$, dan 0,33 (atau $\simeq 1 / 3$ ) untuk mold nonstandard B.

7. Rasio peningkatan nilai California Bearing Ratio (CBR)-unsoaked dengan mold uji non-standard terhadap nilai CBR-unsoaked dengan mold uji CBR standard beturutturut adalah; 1,67 (atau $\simeq$ 3/2) untuk uji dengan mold standard Proctor, 2,04 (atau $\simeq$ 2/1) untuk uji dengan mold non-standard A, dan 3,08 (atau $\simeq 3 / 1$ ) untuk uji dengan mold non-standard $\mathrm{B}$.

8. Rasio pengurangan diameter mold berbanding terbalik dengan rasio peningkatan nilai CBR.

\section{DAFTAR PUSTAKA}

1. ASTM D 1883, Standard Test Methods for CBR (California Bearing Ratio) of Laboratory-Compacted Soils, Annual Book of ASTM Standards.

2. ASTM D 2216, Standard Test Methods for Laboratory Determination of Water (Moisture Content) of Soil and Rock by Mass, Annual Book of ASTM Standards.

3. ASTM D 698, Standard Test Methods for Laboratory Compaction Characteristics of Soil Using Standard Effort, Annual Book of ASTM Standards.

4. Das, B.M. and Shoban, K, 2014, Principles of Geotechnical Engineering, SI, $8^{\text {th }}$ Ed., Cengage Learning, Standford, USA.

5. Holtz, R.D and Kovacs, W.D., 1981, An Introduction to Geotechnical Engineering, Prentice Hall, New Jersey, USA.

6. XP CEN ISO/TS 17892-3, 2005, Laboratory Testing of Soil-Part 3: Determination of Particle Density - Pycnometer Method, French Standardizaation, Geotechnical Investigation and Testing. 